\title{
MACROECONOMIC STABILITY AND TRANSPORT COMPANIES' SUSTAINABLE DEVELOPMENT IN THE EASTERN EUROPEAN UNION
}

\author{
Michał COMPOREK ${ }^{(\mathbb{D}}$, Magdalena KOWALSKA ${ }^{\circledR}$, Anna MISZTAL ${ }^{*}$ \\ Faculty of Economics and Sociology, University of Lodz, Lodz, Poland
}

Received 10 July 2020; accepted 27 August 2021; first published online 14 December 2021

\begin{abstract}
The paper's primary aim is to evaluate the influence of macroeconomic stability on transport companies' sustainable development in the eastern EU from 2008 to 2019. The first part discusses the theoretical problems. The empirical part includes the methodology, results of the research and conclusions. To determine the relationship between variables, we use Pearson's $\mathrm{R}$ and the Ordinary Least Square Method. The contribution to knowledge is using the pentagon of macroeconomic stability to evaluate macroeconomic stabilisation's influence on transport companies' sustainable development. The results indicate that macroeconomic stability is one of the essential determinants of the transport companies' sustainable development. According to Pearson's $\mathrm{R}$, the highest level of dependence is in Slovenia (0.96), Bulgaria (0.9), and Slovenia (0.83). The lowest is in Latvia (0.69). The OLS regression results indicate that the highest significance is in Slovakia $\left(\alpha_{1}=1.994\right)$, the lowest is in Lithuania $\left(\alpha_{1}=0.691\right)$. The states' economic policies should favour the freedom to conduct business, create appropriate legal regulations, and support ecological investments. It is necessary to act for a stable and fair tax system, ensure access to finance. The issue is contemporary and requires further analysis.
\end{abstract}

Keywords: sustainable development, economic growth, macroeconomic stability, transport companies, eastern European Union, economic analysis.

JEL Classification: D22, E10, Q56.

\section{Introduction}

The relationship between macroeconomic stability $\left(\mathrm{M}_{\mathrm{SP}}\right)$ and transport companies' sustainable development $\left(\mathrm{SD}_{\mathrm{TC}}\right)$ is a current and important issue in climate degradation. The literature on companies' sustainable development is gaining importance and requires more in-depth and broader analysis (Evers, 2018; Chang, 2020).

Researchers undertake theoretical analyzes of sustainable development, focusing on its evaluation and development determinants (Bordon \& Schmitz, 2015). Many of them focus

*Corresponding author. E-mail: anna.misztal@uni.lodz.pl

Copyright (c) 2022 The Author(s). Published by Vilnius Gediminas Technical University

This is an Open Access article distributed under the terms of the Creative Commons Attribution License (http://creativecommons. org/licenses/by/4.0/), which permits unrestricted use, distribution, and reproduction in any medium, provided the original author and source are credited. 
on individual economic entities' situation (Mao et al., 2018), analyzes reports on sustainable development of companies (Harymawan et al., 2020), and attempts to evaluate and measure the companies' sustainable development and determine its determinants (Misztal, 2019; Matinaro et al., 2019; Comporek et al., 2021). Some researchers analyze transport companies in terms of their impact on the natural environment (Brussel et al., 2019; Pieloch-Babiarz et al., 2021); analyzes focus on green supply chains, ecological innovations (Andersson \& Forslund, 2018) or an attempt to identify determinants influencing the sustainable development of transport companies (Brussel et al., 2019).

Although the macroeconomic stability for the development of companies is the subject of analyzes and scientific considerations, there is a certain insufficiency, as there are no analyzes of the influence of $\mathrm{M}_{\mathrm{SP}}$ on $\mathrm{SD}_{\mathrm{TC}}$. Researchers indicate that macroeconomic situations, including the level of GDP, inflation, unemployment, and the trade balance, affect the transport sector (Misztal \& Kowalska, 2020; Comporek et al., 2021). Investigating the nature and direction of these links will increase the dynamics of companies' sustainable development and implement a more effective economic and environmental policy.

The paper's primary aim is to evaluate the influence of $\mathrm{M}_{\mathrm{SP}}$ on $\mathrm{SD}_{\mathrm{TC}}$ in the eastern $\mathrm{EU}$ from 2008 to 2019. The research supplements the literature on the subject and is important from the point of view of implementing states' economic policy. To evaluate the statistical relationship between variables, the Authors use the Ordinary Least Square Method, which is commonly used for similar analyzes (Oberhofer \& Dieplinger, 2014). The estimated model is linear and fulfils the conditions necessary for the application of this method.

The research sample includes transport companies from the countries of the eastern European Union. The research sample covers the years from 2008 to 2019. Transport companies were selected for the research sample due to their role in developing other economic sectors. Moreover, this sector has one of the largest negative impacts on the natural environment.

The structure of the paper is as follows: an introduction, a literature review, a research methodology, research results, conclusions, and references.

The Authors discuss selected theoretical issues connected with the sustainable development of transport companies in the context of macroeconomic stability. The empirical part of the paper presents the research results and conclusions. We build the single equation model, use the Pearson' $\mathrm{R}$ and the Ordinary Least Square Method (OLS) to verify the research hypothesis. The research's significant limitation. It does not consider the situation before the economic crisis and its impact on companies' sustainable development. Also, only one explanatory variable was included in the model. Therefore, further research should be carried out to identify the key determinants for companies' sustainable development. Moreover, the model considers only quantitative data, which is also a significant limitation.

\section{The literature review}

Sustainable development means achieving the best economic performance while respecting the environment and social development (Evers, 2018; Cohen et al., 2021). Over the years, the concept of sustainable development evolved significantly, becoming a key reference area in many global programs and initiatives for the common good (Mao et al., 2018; Pieloch- 
Babiarz et al., 2021). Business activities are fundamental for stable economic growth. Unfortunately, it has very often a negative influence on the natural environment (Škare \& Golja, 2013; Słupik \& Lorek, 2019). Companies should implement the assumptions of sustainable development into their business processes (Salari \& Bhuiyan, 2018; Powe, 2020). It requires achieving the best possible financial results, multidimensional management, testing various business models and scenarios, implementing continuous learning processes, looking for and levelling threats around achieving sustainable development goals (Misztal, 2019; Saygili et al., 2021). The implementation of sustainable development tasks provides a competitive advantage (Suprayoga et al., 2020).

Numerous empirical studies focus on the environmental activities of transport companies (Valjevac et al., 2018; Banik \& Lin, 2019). It is necessary to minimize the negative impact of transport entities, create balanced transport systems, and implement eco-innovation (Zikic, 2018). Ecological activities should reduce emissions of harmful substances and waste, minimize the use of non-renewable resources, reduce noise, etc. (Misztal, 2019; Cohen et al., 2021).

Sustainable development of transport companies' factors is internal (a financial situation, environmental awareness, etc.) and external (micro and macroeconomic factors) factors (Bordon \& Schmitz, 2015; Andersson \& Forslund, 2018; Brussel et al., 2019). One crucial factor for sustainable development is macroeconomic stabilization, which means lasting economic balance (internal and external) in both the real and monetary aspects (establishing a macroeconomic system characterized by an equilibrium of flows and stocks alike). It eliminates uncertainty in business and boosts future economic activity growth (Kołodko, 1993; Sokolov Mladenović et al., 2019; Chang, 2020).

The company's sustainable development is strongly associated with the level of macroeconomic growth (Škare \& Hasić, 2016; Comporek et al., 2021). A higher economic level means higher expenditure on research and development, greater availability of knowledge and greater environmental awareness of customers. Thus, stable economic growth leads to rationalization of decisions in environmental protection (Cek \& Eyupoglu, 2020).

Macroeconomic stability understood as stable conditions for economic growth is of key importance for sustainable economic development. The improvement of stability is related to improving business conditions and stable legal regulations (Misztal \& Kowalska, 2020; Lisiński et al., 2020). Most researchers emphasize that high GDP, low inflation, and low unemployment rate increase confidence and improve its sustainable development (Krajnakova et al., 2018; Misztal, 2019). The companies' sustainable development is dependent on interest rates, foreign investments, and government expenditure (Barkauskas et al., 2015).

Macroeconomic stability ensures full and productive employment and decent work for all people. Hence, from the perspective of the sustainable development of companies, a decrease in the unemployment rate has a positive effect on the sustainable development of companies (Fedulova et al., 2019). As for the issue of interest rates, they largely influence the investment decisions of companies. Higher interest rates mean a higher credit price and lower ecological innovations (Wu et al., 2021).

Macroeconomic stability affects the sentiments and expectations of entrepreneurs about the future. A good economic situation is conducive to undertaking ecological investments (Kekre, 2016; Raczkowski, 2015; Harting, 2019). There is also a positive correlation between macro- 
economic conditions and consumer expectations. There is pressure on companies in developed countries to take care of the environmental and social aspects (Pieloch-Babiarz et al., 2021).

\section{The methodology of the research}

The paper's primary aim is to evaluate the influence of macroeconomic stability on transport companies' sustainable development in the eastern EU from 2008 to 2019. The research period and the sample selection result from the adopted purpose and the availability of data. The study's significant limitation is that it does not consider the situation before the economic crisis and its impact on companies' sustainable development. Moreover, the model considers only quantitative data, which is also a significant limitation.

We focus on eleven eastern European Union countries, which have several common characteristics, including geolocation, history, economic systems transformation, and business operations changes.

The study refers to the transport companies, which can contribute to the region (the sample was selected to ensure the results' statistical significance). Not without value is that transport companies emit several pollutants, which hurt the natural environment and human health and life.

The central research hypothesis is "Macroeconomic stability has a statistically significant influence $(\mathrm{p}<0.05)$ on the transport companies' sustainable development in the eastern European Union in the period 2008-2019”. To evaluate the significance of the variable $\mathrm{M}_{\mathrm{SP}}$ 's influence on the variable $\mathrm{SD}_{\mathrm{TC}}$, we verify the hypothesis:

$$
\mathrm{H}_{0}: \alpha_{j}=0 \text {, }
$$

with the alternative hypothesis $\mathrm{H}_{1}: \alpha_{j} \neq 0$ ( $\mathrm{p}$-value $\left.<0.05\right)$.

Assumption: macroeconomic stability is one of the decisive determinants affecting green business investments.

Also, highlighted the sub-hypothesis:

- H1: "The transport companies' sustainable development in the eastern part of the EU has a positive trend from 2008 to 2019".

The following equation describes the dynamics:

we verify the hypothesis:

$$
\mathrm{SD}_{\mathrm{TC}}=\alpha_{1} \mathrm{t}+\alpha_{0}
$$

$$
\mathrm{H}_{0}=\alpha_{1}>0
$$

the alternative hypothesis $\mathrm{H}_{1}=\alpha_{1}<0$.

Justification for the $\mathrm{H} 1$ hypothesis: actions taken by state and EU authorities to initiate environmental and social investments, including the introduction of standards and legal principles in environmental protection. The positive trend is also the result of the increased environmental awareness of entrepreneurs and customers.

- H2: "The macroeconomic stability in the eastern EU has a positive trend from 2008 to 2019 ”.

$$
\mathrm{M}_{\mathrm{SP}}=\alpha_{1} \mathrm{t}+\alpha_{0}
$$


we verify the hypothesis $\mathrm{H}_{0}=\alpha_{1}>0$;

the alternative hypothesis $\mathrm{H}_{1}=\alpha_{1}<0$.

Justification for the $\mathrm{H} 2$ hypothesis: the research period covers the time to recover from the economic slowdown and slow growth in corporate investment.

- H3: "The highest average value of the transport companies' sustainable development $\left(\mathrm{SD}_{\mathrm{TC}}\right)$ is in countries with the highest mean value of the macroeconomic stability $\left(\mathrm{M}_{\mathrm{SP}}\right)^{\prime \prime}$.

We verify the hypothesis $H_{0}=\max \left(\overline{S D_{T C}}\right)$ is in the country with the highest $\max \left(\overline{M_{S P}}\right)$; the alternative hypothesis $H_{1} \neq \max \left(\overline{S D_{T C}}\right)$ is in the country with the highest $\max \left(\overline{M_{S P}}\right)$.

Justification for the $\mathrm{H} 3$ hypothesis: $M_{S P}$ means stimulating economic growth, increasing employment, ensuring internal balance (by reducing the inflation rate), and providing external balance (by striving to achieve the balance of payments). Thus, attain $M_{S P}$ has a positive effect on the level of investment in the company's sector.

The transport companies' sustainable development $\left(S D_{T C}\right)$ is a sum of economic $\left(\mathrm{ED}_{\mathrm{TE}}\right)$, social $\left(\mathrm{SOD}_{\mathrm{TE}}\right)$, and environmental $\left(\mathrm{ENVD}_{\mathrm{TE}}\right)$ development. Precisely, 25 explaining variables that meet the statistical, substantial, and formal criteria ( $\mathrm{p}>|0.75|)$ (Dziekański, 2014).

The variables are stimulants (positively affect synthetic indicators) andstimulants (alytical variables whose increase affects the decrease in the sustainabldevelopment indicator).

We use following variables to assess the indicators:

- economic development $\left(\mathrm{ED}_{\mathrm{TC}}\right)$ : stimulants [the number of transport companies, turnover [mil euro], production value [mil euro], value added [mil euro], gross operating surplus [mil euro], total buying of products [mil euro], total investments [mil euro], investment rate [\%]],

- social development $\left(\mathrm{SOD}_{\mathrm{TC}}\right)$ : stimulants [wages [mil euro], costs of social security [mil euro], employee- number, turnover per employee [thousand euro], worker's productivity [thousand euro], gross value added per capita [thousand euro], employment growth [\%], investment per employee [thous euro]] and destimulants [personnel costs [mil euro], share of personnel costs in production \%]],

- environmental development $\left(\mathrm{ENVD}_{\mathrm{TC}}\right)$ : destimulants [emissions in tons of $\mathrm{CO}_{2}, \mathrm{CH}_{4}$, $\left.\mathrm{N}_{2} \mathrm{O}, \mathrm{SO}_{2}, \mathrm{CO}, \mathrm{NO}, \mathrm{NH}_{3}\right]$.

To calculate SDTC we used the following formula:

$$
S D_{T C i}=\frac{1}{n} \sum_{j=1}^{n} E D_{T C i j}+\frac{1}{n} \sum_{j=1}^{n} S O D_{T C i j}+\frac{1}{n} \sum_{j=1}^{n} E N V D_{T C i j},
$$

where $n$ - number of observations, others like above.

Then, the unification of variables was performed using the formula (Pieloch et al., 2021):

- into the stimulants:

$$
S D_{T C i j}=\frac{S D_{T C i j}-\min _{i}\left\{S D_{T C i j}\right\}}{\max _{i}\left\{S D_{T C i j}\right\}-\min _{i}\left\{S D_{T C i j}\right\}} ;
$$

- into the destimulants:

$$
S D_{T C i j}=\frac{\max _{i}\left\{S D_{T C i j}\right\}-S D_{T C i j}}{\max _{i}\left\{S D_{T C} i j\right\}-\min _{i}\left\{S D_{T C i j}\right\}} ; S D_{T C i j} \in[0 ; 1] .
$$


Then, we create $\mathrm{M}_{\mathrm{SP}}$ based on the following formula (Kołodko, 1993):

$$
\begin{aligned}
& M_{S P}=M_{S P 1}+M_{S P 2}= \\
& {[(\Delta G D P U)+(U H I C P)+(H I C P G)+(G C A)+(C A \Delta G D P)] 0.475}
\end{aligned}
$$

where $\triangle G D P-\triangle$ gross demestic product, HICP - Harmonised Index of Consumer Prices, $U$ - unemployment rate, $G$ - government debt, $C A$ - current account balance to gross domestic product.

We use the Pearson' R to measure the correlation between $\mathrm{M}_{\mathrm{SP}}$ and SDTC and create two types of the regression model (the model meets the conditions for the application of the least square method) based on the formula:

$$
\begin{aligned}
& \text { Model 1: } S D_{T C}=\infty_{0}+\infty_{1} M_{S P 1}+\infty_{2} M_{S P 2}+\varepsilon_{i}, \\
& \text { Model 2: } S D_{T C}=\infty_{0}+\infty_{1} M_{S P}+\varepsilon_{i} .
\end{aligned}
$$

\section{Result of the research}

The research sample consists of 44\% Polish (146 039), 12\% Czech and Romanian (39 424, 39 646), 9\% Hungarian (28 926), 6\% Bulgarian (20 625), 5\% Slovak (15 266), 3\% Slovenian, Lithuanian and Croatian (8 580, 11 286, 9460$), 2 \%$ Latvian (6 672) and 1\% Estonian (4 806) transport companies (Figure 1).

Figure 2 presents $\mathrm{SD}_{\mathrm{TC}}$ from 2008 to 2019. All countries show a positive trend in the $\mathrm{SD}_{\mathrm{TC}}$ over the analyzed period, which should be assessed as a favourable situation, which means that activities in the transport sector undertaken for economic, social, and environmental development are effective and efficient. The highest dynamics is in Hungary $\left(\mathrm{SD}_{\mathrm{TC}}=\right.$ $\left.0.0523 t+0.2 ; \mathrm{R}^{2}=0.9585\right)$ and in Estonia $\left(\mathrm{SD}_{\mathrm{TC}}=0.052 \mathrm{t}+0.2485\right)$. The $\mathrm{SD}_{\mathrm{TC}}$ fell during the economic crisis of 2008, and after 2012, it began to rise rapidly in all countries.

Figure 3 presents $M_{S P}$ in east EU countries. There is a positive trend in the $M_{S P}$ in the analyzed countries. In most countries, its values slightly decreased during the crisis and then increased after 2012. The exceptions are Hungary, where the indicator has decreased since 2016, and the Czech Republic and Romania, where the indicator has decreased since 2017. The highest trend of $\mathrm{M}_{\mathrm{SP}}$ is in Lithuania $\left(\mathrm{M}_{\mathrm{SP}}=0.0322 t+0.2509, \mathrm{R}^{2}=0.8157\right)$, the lowest in Slovakia $\left(\mathrm{M}_{\mathrm{SP}}=0.0136 \mathrm{t}+0.3474, \mathrm{R}^{2}=0.5433\right) . \mathrm{M}_{\mathrm{SP}}$ in all countries increase, which is a

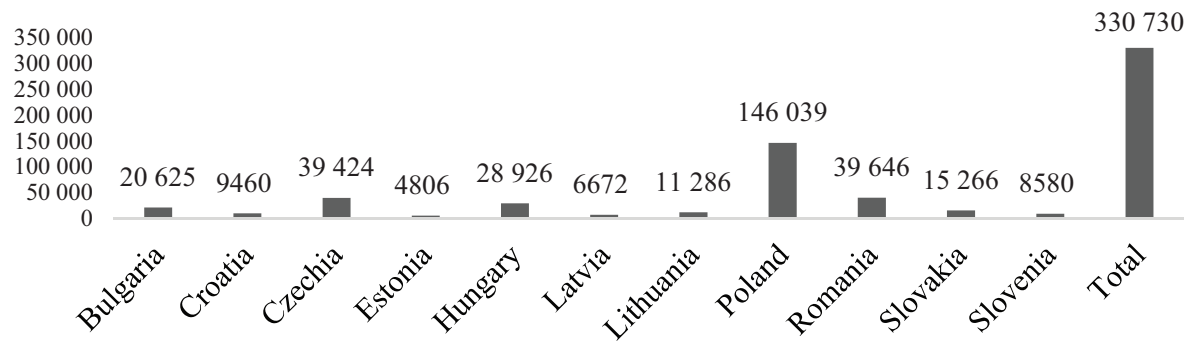

Figure 1. The number of transport companies (2008-2019) (source: Eurostat, n.d.) 


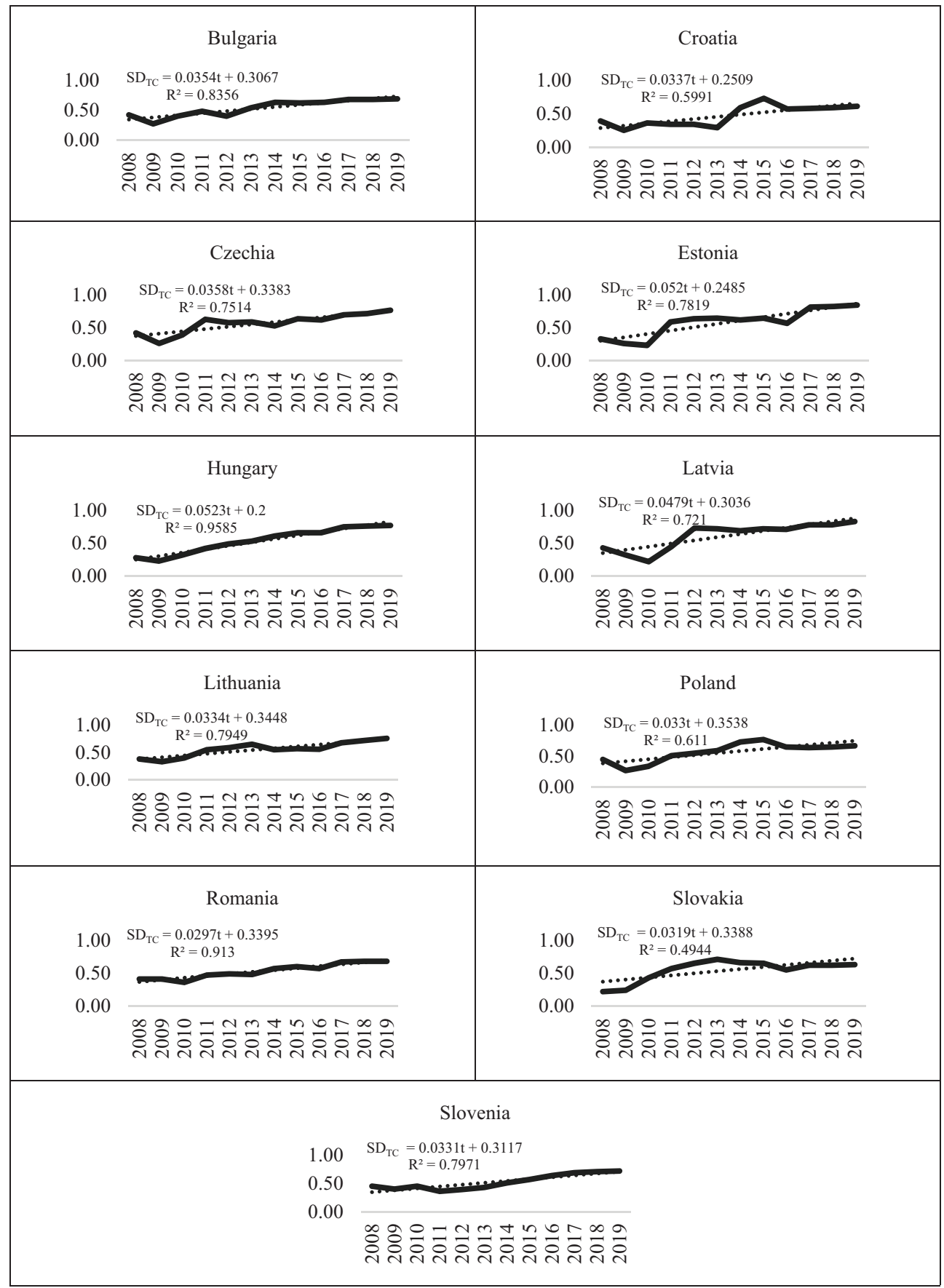

Figure 2. The sustainable development of transport companies 2008-2019 (source: own calculations based on Eurostat database) 


\begin{tabular}{|c|c|c|c|c|}
\hline \multicolumn{3}{|c|}{ Bulgaria } & \multicolumn{2}{|r|}{ Croatia } \\
\hline 1.00 & \multicolumn{2}{|l|}{$\begin{array}{l}\mathrm{M}_{\mathrm{SP}}=0.029 \mathrm{t}+0.318 \\
\mathrm{R}^{2}=0.8611\end{array}$} & \multirow{3}{*}{$\begin{array}{l}1.00 \\
0.50 \\
0.00\end{array}$} & $\begin{array}{c}\mathrm{M}_{\mathrm{SP}}=0.0299 \mathrm{t}+0.2748 \\
\mathrm{R}^{2}=0.9241\end{array}$ \\
\hline 0.50 & non & & & \\
\hline 0.00 & \multicolumn{2}{|c|}{ 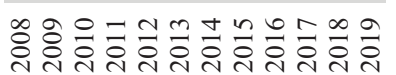 } & & 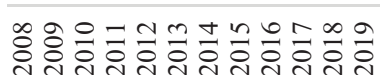 \\
\hline \multicolumn{3}{|c|}{ Czechia } & \multicolumn{2}{|r|}{ Estonia } \\
\hline \multirow{3}{*}{$\begin{array}{l}1.00 \\
0.50 \\
0.00\end{array}$} & \multirow{3}{*}{\multicolumn{2}{|c|}{$\begin{array}{l}\mathrm{M}_{\mathrm{SP}}=0.0175 \mathrm{t}+0.397 \\
\mathrm{R}^{2}=0.6955\end{array}$}} & \multirow{3}{*}{$\begin{array}{l}1.00 \\
0.50 \\
0.00\end{array}$} & $\begin{array}{c}M_{S P}=0.0223 t+0.3767 \\
R^{2}=0.6728\end{array}$ \\
\hline & & & & \multirow{2}{*}{ 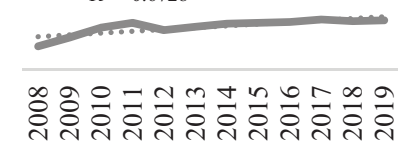 } \\
\hline & & & & \\
\hline \multicolumn{3}{|c|}{ Hungary } & \multicolumn{2}{|r|}{ Latvia } \\
\hline 1.00 & \multicolumn{2}{|l|}{$\begin{array}{l}\mathrm{M}_{\mathrm{SP}}=0.0205 \mathrm{t}+0.3845 \\
\mathrm{R}^{2}=0.6323\end{array}$} & \multirow{3}{*}{$\begin{array}{l}1.00 \\
0.50 \\
0.00\end{array}$} & $\begin{array}{c}\mathrm{M}_{\mathrm{SP}}=0.0242 \mathrm{t}+0.2861 \\
\mathrm{R}^{2}=0.7863\end{array}$ \\
\hline 000 & & & & \\
\hline & \multicolumn{2}{|c|}{ 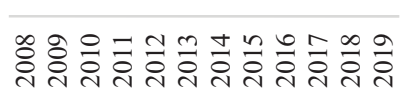 } & & 总 \\
\hline \multirow{4}{*}{$\begin{array}{l}1.00 \\
0.50 \\
0.00\end{array}$} & \multicolumn{2}{|l|}{ Lithuania } & \multicolumn{2}{|c|}{ Poland } \\
\hline & \multicolumn{2}{|c|}{$\begin{array}{c}\mathrm{M}_{\mathrm{SP}}=0.0322 \mathrm{t}+0.2509 \\
\mathrm{R}^{2}=0.8157\end{array}$} & \multirow{3}{*}{$\begin{array}{l}1.00 \\
0.50 \\
0.00\end{array}$} & $\begin{array}{l}\mathrm{M}_{\mathrm{SP}}=0.0242 \mathrm{t}+0.3071 \\
\mathrm{R}^{2}=0.9412\end{array}$ \\
\hline & 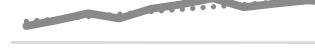 & & & \\
\hline & \multicolumn{2}{|c|}{ 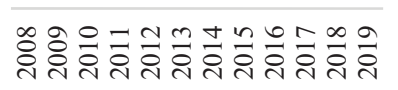 } & & 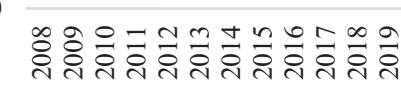 \\
\hline \multirow{4}{*}{$\begin{array}{l}1.00 \\
0.50 \\
0.00\end{array}$} & Romania & & \multirow{4}{*}{$\begin{array}{l}1.00 \\
0.50 \\
0.00\end{array}$} & Slovakia \\
\hline & \multicolumn{2}{|c|}{$\begin{array}{l}\mathrm{M}_{\mathrm{SP}}=0.0184 \mathrm{t}+0.2988 \\
\mathrm{R}^{2}=0.5413\end{array}$} & & $\begin{array}{c}\mathrm{M}_{\mathrm{SP}}=0.0136 \mathrm{t}+0.3474 \\
\mathrm{R}^{2}=0.5433\end{array}$ \\
\hline & (1) & לع. & & 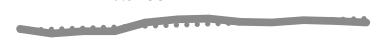 \\
\hline & \multicolumn{2}{|c|}{ 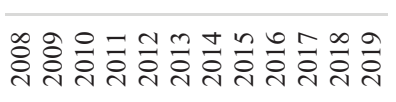 } & & 完 \\
\hline \multicolumn{5}{|c|}{ Slovenia } \\
\hline & \multicolumn{4}{|c|}{$\begin{array}{l}\mathrm{M}_{\mathrm{SP}}=0.0311 \mathrm{t}+0.3261 \\
\mathrm{R}^{2}=0.8789\end{array}$} \\
\hline & \multicolumn{4}{|l|}{0.50} \\
\hline & 0.00 & 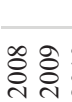 & 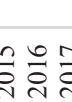 & $\stackrel{\infty}{\vec{i}} \vec{i}$ \\
\hline
\end{tabular}

Figure 3. $\mathrm{M}_{\mathrm{SP}}$ in east EU from 2008 to 2019

(source: own calculations based on Eurostat database) 


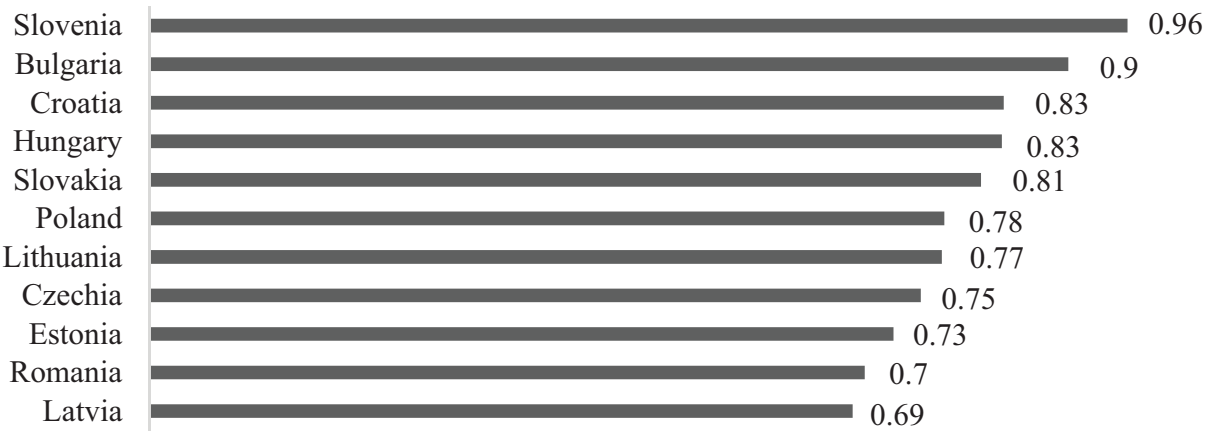

Figure 4. Pearson's R between $\mathrm{M}_{\mathrm{SP}}$ and $\mathrm{SD}_{\mathrm{TC}}(2008-2019), \mathrm{p}<0.05$ (source: own calculations based on Eurostat database)

positive phenomenon and means that economic policy in conjunction with EU funds brings positive results.

Figure 4 presents the result of the correlations between $\mathrm{M}_{\mathrm{SP}}$ and $\mathrm{SD}_{\mathrm{TC}}$. The Pearson's $\mathrm{R}$ between $\mathrm{SD}_{\mathrm{TC}}$ and $\mathrm{M}_{\mathrm{SP}}$ is significant at $\mathrm{p}<0.05$. The highest correlation is in Slovenia (0.96), the lowest in Latvia (0.69). The correlations between the variables are either strong or very strong, which proves a high degree of relations between the variables.

Table 1 presents the OLS regression. All factors have a positive influence on transport companies. The highest impact of $\mathrm{M}_{\mathrm{SP} 1}$ is in Estonia (4.868), the lowest is in Romania (0.495). The highest impact of $\mathrm{M}_{\mathrm{SP} 2}$ is in Slovakia (2.392) and the lowest is in Estonia (0.087). In most countries, the $\mathrm{M}_{\mathrm{SP} 1}$ and $\mathrm{M}_{\mathrm{SP} 2}$ are statistically significant (except $\mathrm{M}_{\mathrm{SP} 1}$ in Slovakia). The coefficient of determination $\left(\mathrm{R}^{2}\right)$ is from $0.573\left(\mathrm{M}_{\mathrm{SP} 1}, \mathrm{M}_{\mathrm{SP} 2}\right.$ and $\mathrm{SD}_{\mathrm{TC}}$ in Czechia $)$ to $0.981\left(\mathrm{M}_{\mathrm{SP} 1}\right.$, $\mathrm{M}_{\mathrm{SP} 2}$ and $\mathrm{SD}_{\mathrm{TC}}$ in Romania).

$\mathrm{M}_{\mathrm{SP}}$ has a positive influence on the transport companies' sustainable development. The highest impact is in Slovakia (1.994), while the lowest is in Lithuania (0.691) (Table 1).

Table 1. Results of Ordinary Least Square regressions (source: own calculations based on Eurostat database)

\begin{tabular}{|c|c|c|c|c|c|c|c|c|}
\hline \multirow{2}{*}{$\begin{array}{c}\text { Dependent } \\
\text { variable } \\
\left(S D_{T E}\right)\end{array}$} & \multicolumn{4}{|c|}{$S D_{T C}=\infty_{0}+\infty_{1} M_{S P 1}+\infty_{2} M_{S P 2}+\varepsilon_{i}$} & \multicolumn{4}{|c|}{$S D_{T C}=\infty_{0}+\infty_{1} M_{S P}+\varepsilon_{i}$} \\
\hline & OLS & Coeff. & P-val. & $\mathrm{R}^{2}$ & OLS & Coeff. & P-val. & $\mathrm{R}^{2}$ \\
\hline \multirow{3}{*}{ Bulgaria } & Const & -0.101 & 0.5675 & \multirow{3}{*}{0.809} & Const & -0.041 & 0.6642 & \multirow{3}{*}{0.806} \\
\hline & $\mathrm{M}_{\mathrm{SP} 1}$ & 1.362 & $0.0381^{\star *}$ & & \multirow{2}{*}{$\mathrm{M}_{\mathrm{SP}}$} & \multirow{2}{*}{1.137} & \multirow{2}{*}{$<0.0001^{* * *}$} & \\
\hline & $\mathrm{M}_{\mathrm{SP} 2}$ & 1.073 & $0.0014^{\star * *}$ & & & & & \\
\hline \multirow{3}{*}{ Croatia } & const & -0.111 & 0.5068 & \multirow{3}{*}{0.700} & Const & -0.076 & 0.5317 & \multirow{3}{*}{0.697} \\
\hline & $\mathrm{M}_{\mathrm{SP} 1}$ & 1.368 & $0.0431^{\star}$ & & \multirow{2}{*}{$\mathrm{M}_{\mathrm{SP}}$} & \multirow{2}{*}{1.168} & \multirow{2}{*}{$0.0007^{\star * *}$} & \\
\hline & $\mathrm{M}_{\mathrm{SP} 2}$ & 1.072 & $0.0204^{* *}$ & & & & & \\
\hline \multirow{3}{*}{ Czechia } & Const & -0.285 & 0.4236 & \multirow{3}{*}{0.573} & Const & -0.197 & 0.3783 & \multirow{3}{*}{0.568} \\
\hline & $\mathrm{M}_{\mathrm{SP} 1}$ & 2.195 & $0.0159^{\star}$ & & \multirow{2}{*}{$\mathrm{M}_{\mathrm{SP}}$} & \multirow{2}{*}{1.503} & \multirow{2}{*}{$0.0047^{\star * *}$} & \\
\hline & $\mathrm{M}_{\mathrm{SP} 2}$ & 0.767 & $0.0343^{*}$ & & & & & \\
\hline
\end{tabular}


End of Table 1

\begin{tabular}{|c|c|c|c|c|c|c|c|c|}
\hline \multirow{2}{*}{$\begin{array}{c}\text { Dependent } \\
\text { variable } \\
\left(S D_{T E}\right)\end{array}$} & \multicolumn{4}{|c|}{$S D_{T C}=\infty_{0}+\infty_{1} M_{S P 1}+\infty_{2} M_{S P 2}+\varepsilon_{i}$} & \multicolumn{4}{|c|}{$S D_{T C}=\infty_{0}+\infty_{1} M_{S P}+\varepsilon_{i}$} \\
\hline & OLS & Coeff. & P-val. & $\mathrm{R}^{2}$ & OLS & Coeff. & P-val. & $\mathrm{R}^{2}$ \\
\hline \multirow{3}{*}{ Estonia } & Const & -0.899 & $0.0195^{\star *}$ & \multirow{3}{*}{0.739} & Const & -0.218 & 0.3944 & \multirow{3}{*}{0.528} \\
\hline & $\mathrm{M}_{\mathrm{SP} 1}$ & 4.868 & $0.0043^{* * *}$ & & \multirow{2}{*}{$\mathrm{M}_{\mathrm{SP}}$} & \multirow{2}{*}{1.539} & \multirow{2}{*}{$0.0074^{* * *}$} & \\
\hline & $\mathrm{M}_{\mathrm{SP} 2}$ & 0.087 & $0.0004^{*}$ & & & & & \\
\hline \multirow{3}{*}{ Hungary } & Const & -0.853 & $0.0005^{\star * *}$ & \multirow{3}{*}{0.901} & Const & -0.345 & $0.0973^{\star}$ & \multirow{3}{*}{0.694} \\
\hline & $\mathrm{M}_{\mathrm{SP} 1}$ & 4.266 & $<0.0001^{\star * *}$ & & \multirow{2}{*}{$\mathrm{M}_{\mathrm{SP}}$} & \multirow{2}{*}{1.707} & \multirow{2}{*}{$0.0008^{\star * *}$} & \\
\hline & $\mathrm{M}_{\mathrm{SP} 2}$ & 0.577 & $0.0222^{\star}$ & & & & & \\
\hline \multirow{3}{*}{ Latvia } & Const & -0.294 & $0.0252^{* *}$ & \multirow{3}{*}{0.898} & Const & -0.016 & 0.9431 & \multirow{3}{*}{0.472} \\
\hline & $\mathrm{M}_{\mathrm{SP} 1}$ & 3.176 & $<0.0001^{\star * *}$ & & \multirow{2}{*}{$\mathrm{M}_{\mathrm{SP}}$} & \multirow{2}{*}{1.422} & \multirow{2}{*}{$0.0136^{\star *}$} & \\
\hline & $\mathrm{M}_{\mathrm{SP} 2}$ & 0.269 & $0.0284^{*}$ & & & & & \\
\hline \multirow{3}{*}{ Lithuania } & Const & 0.156 & 0.1731 & \multirow{3}{*}{0.648} & Const & 0.227 & $0.0235^{\star *}$ & \multirow{3}{*}{0.599} \\
\hline & $\mathrm{M}_{\mathrm{SP} 1}$ & 1.074 & $0.0209^{\star *}$ & & \multirow{2}{*}{$\mathrm{M}_{\mathrm{SP}}$} & \multirow{2}{*}{0.691} & \multirow{2}{*}{$0.0031^{* * *}$} & \\
\hline & $\mathrm{M}_{\mathrm{SP} 2}$ & 0.485 & $0.0292^{\star}$ & & & & & \\
\hline \multirow{3}{*}{ Poland } & const & -0.026 & 0.9226 & \multirow{3}{*}{0.603} & Const & -0.038 & 0.8165 & \multirow{3}{*}{0.603} \\
\hline & $\mathrm{M}_{\mathrm{SP} 1}$ & 1.239 & $0.0154^{\star}$ & & \multirow{2}{*}{$\mathrm{M}_{\mathrm{SP}}$} & \multirow{2}{*}{1.306} & $0003 * * *$ & \\
\hline & $\mathrm{M}_{\mathrm{SP} 2}$ & 1.362 & $0.0282^{*}$ & & & & $0.003^{x+1}$ & \\
\hline & Const & 0.014 & 0.4803 & & Const & 0.181 & 0.1507 & \\
\hline Romania & $\mathrm{M}_{\mathrm{SP} 1}$ & 0.495 & $0.0001^{\star * *}$ & 0.981 & & 0839 & $00115^{\text {** }}$ & 0.488 \\
\hline & $\mathrm{M}_{\mathrm{SP} 2}$ & 0.923 & $<0.0001^{\star * \star}$ & & $\mathrm{M}_{\mathrm{SP}}$ & 0.839 & $0.0115^{* x}$ & \\
\hline & Const & -0.194 & 0.4292 & & Const & -0.325 & 0.135 & \\
\hline Slovakia & $\mathrm{M}_{\mathrm{SP} 1}$ & 1.300 & 0.1367 & 0.698 & & 1994 & & 0.660 \\
\hline & $\mathrm{M}_{\mathrm{SP} 2}$ & 2.393 & $0.0028^{* * *}$ & & $\mathrm{M}_{\mathrm{SP}}$ & 1.994 & $0.0013^{x x x}$ & \\
\hline & const & -0.047 & 0.4494 & & Const & -0.029 & 0.6129 & \\
\hline Slovenia & $\mathrm{M}_{\mathrm{SP} 1}$ & 1.217 & $0.0003^{* * *}$ & 0.920 & & 1049 & $<0.0001^{\star * *}$ & 0.913 \\
\hline & $\mathrm{M}_{\mathrm{SP} 2}$ & 0.946 & $0.000^{\star * \star}$ & & $\mathrm{M}_{\mathrm{SP}}$ & 1.049 & $<0.0001$ & \\
\hline
\end{tabular}

The results of the research allow confirming the research hypothesis $(\mathrm{H})$. The study gathered evidence that macroeconomic stabilization has a statistically significant impact on transport companies' sustainable development from 2008 to 2019. According to the Pearson's $\mathrm{R}$, the highest level of dependence occurred in Slovenia (0.96), Bulgaria (0.9), and Slovenia (0.83). The lowest in Latvia (0.69). The OLS regression results indicate that the highest impact of $\mathrm{M}_{\mathrm{SP}}$ on $\mathrm{SD}_{\mathrm{TC}}$ is in Slovakia $\left(\alpha_{1}=1.994\right)$ while the lowest is in Lithuania $\left(\alpha_{1}=0.691\right)$.

In the analyzed period in the eastern part of the European Union, there are positive phenomena that go hand in hand, as there are balanced economic growth and sustainable transport companies' development. Moreover, lasting economic balance leads to an increase in social well-being and changes the conditions for doing business.

The sub-hypothesis $\mathrm{H} 1$ is correct because, in all countries, $\mathrm{SD}_{\mathrm{TC}}$ is positive from 2009 to 2019. It means that entrepreneurs take actions for economic, social, and environmental development. The programs implemented by the European Union and countries work well. 
The sub-hypothesis $\mathrm{H} 2$ is true. In all analyzed countries, it is the positive dynamics of $\mathrm{M}_{\mathrm{SP}}$. This is the result of an improvement in the economic situation, an increase in investments, and an improved positive mood among consumers.

The sub-hypothesis H3 is wrong because only in Estonia, the highest mean value of the sustainable development of transport companies $\left(\mathrm{SD}_{\mathrm{TC}}=0.59\right)$ is accompanied by the highest average value of the macroeconomic stabilization indicator $\left(\mathrm{M}_{\mathrm{SP}}=0.31\right)$.

The model with two explanatory variables $\mathrm{M}_{\mathrm{SP} 1}$ and $\mathrm{M}_{\mathrm{SP} 2}$ does not indicate which group of factors, internal $\left(\mathrm{M}_{\mathrm{SP} 1}\right)$ or external $\left(\mathrm{M}_{\mathrm{SP} 2}\right)$ is crucial for the sustainable development of transport companies. The highest impact of internal factor is in Estonia $\left(\alpha_{1}=4.868\right)$ while the lowest is in Romania $\left(\alpha_{1}=0.495\right)$. The highest impact on external factors is in Slovakia $\left(\alpha_{2}=2.392\right)$, and the lowest in Estonia $\left(\alpha_{2}=0.087\right)$.

The sustainable development of transport companies is very important research issues. This research focuses only on macroeconomic stability, which is a severe limitation. The most important conclusion is that the more advanced countries are, the more meaningful demand for companies to comply with SDG.

Therefore, it is vital to create favorable circumstances for doing green business. From this perspective, the state authorities' role is necessary and essential for the countries' stable development with harmony with nature. The transparent legal regulations and substantive and financial support are also crucial for undertaking ecological investments by companies.

\section{Conclusions}

The sustainable development of the companies is conditioned by several factors, both internal and external. Internal factors include assets and financial possibilities, the adopted business model, the strategy, and the environmental management approach. External factors, including the industry's competitiveness and ecological harmfulness, socio-economic increase in the country and its future perspective, and legal regulations in environmental protection.

The research results indicate that macroeconomic stability (stable economic growth) is one factor determining the transport companies' sustainable development in east EU countries. The Pearson's R and the OLS regression indicate the high correlation between macroeconomic stabilization and transport companies' sustainable development. From 2008 to 2019 , there is a positive dynamic of $\mathrm{SD}_{\mathrm{TC}}$ and $\mathrm{M}_{\mathrm{SP}}$.

The research's significant limitation. It does not consider the situation before the economic crisis and its impact on companies' sustainable development. Also, only one explanatory variable was included in the model. Therefore, further research should be carried out to identify the key determinants for companies' sustainable development. Moreover, the model considers only quantitative data, which is also a significant limitation.

The research results are useful for setting the direction of governments' economic and environmental policies and for managing companies. The directions of the states' economic policies should favour the freedom to conduct business, create appropriate legal regulations, and support the development of ecological investments. It is necessary to act for a stable and fair tax system and ensure access to finance. 
Authorities should use regulatory mechanisms and market control, from corporate governance to verifying the public finances sector (only to create appropriate self-regulating mechanisms). Achieving macroeconomic stability is a challenging task, especially for developing economies. In countries where economic transformation has also taken place, it is crucial to conduct macroeconomic policy to support ecological and pro-social companies' initiatives. Macroeconomic stability strengthens the economy's position and is the starting point for ecological development and reducing the negative influence of economic activities on the natural environment. It affects the credit policy, which is essential for making new environmental investments.

From business managers' perspective, the information about macroeconomic stabilization is vital in defining development strategies and building business models. Maintaining appropriate economic relations affects the moods and expectations of companies and customers. The persistent macroeconomic stabilization leads to an increase in society's welfare and changes the consumption model. Not only economical but also social and environmental issues are gaining in importance.

The $\mathrm{SD}_{\mathrm{TC}}$ and $\mathrm{M}_{\mathrm{SP}}$ have a growing trend. Which indicates that the actions taken so far in the analysed countries are right, although a more comprehensive approach to the development of economies is required. It seems that these countries, apart from taking care of economic development, need to implement environmental protection and community support policies more actively and effectively.

The sustainable development of transport companies is significant as this sector is responsible for some of the highest emissions of harmful substances into the environment. Moreover, the development of the transport sector influences other sectors of the economy.

The research shows the relationship between sustainable development and macroeconomic stabilization, which means implementing current and forecasted macroeconomic information in strategies and business models in business practice. The obtained results also indicate the tasks faced by the ruling states whose role in creating conditions for companies' stable and sustainable development is undeniable.

Macroeconomic stability is only one of the factors influencing the sustainable development of economic entities. It is necessary to conduct further analyses devoted to isolating the determinants of economic, social, and environmental decision-making by companies. Further research will focus on assessing the influence of determinants on the transport companies' sustainable development in the EU. It is also essential to identify the determinants of sustainable development in other companies and conduct a comparative analysis.

\section{References}

Andersson, P., \& Forslund, H. (2018). Developing an indicator framework for measuring sustainable logistics innovation in retail. Measuring Business Excellence, 22(1), 1-13. https://doi.org/10.1108/MBE-04-2017-0017

Banik, D., \& Lin, K. (2019). Business and morals: Corporate strategies for sustainable development in China. Business and Politics, 21(4), 514-539. https://doi.org/10.1017/bap.2019.26 
Barkauskas, V., Barkauskienè, K., Jasinskas, E. (2015). Analysis of macro environmental factors influencing the development of rural tourism: Lithuanian case. Procedia - Social and Behavioral Sciences, 213, 167-172. https://doi.org/10.1016/j.sbspro.2015.11.421

Bordon, I., \& Schmitz, B. (2015). Financial stability as a precondition for the financing of sustainable development in emerging and developing countries (Briefing paper, 23). Deutsches Institut für Entwicklungspolitik (DIE), Bonn.

Brussel, M., Zuidgeest, M., Pfeffer, K., \& Maarseveen, M. V. (2019). Access or accessibility? A critique of the urban transport SDG indicator. International Journal of Geo-Information, 8(2), 67. https://doi.org/10.3390/ijgi8020067

Cek, K., \& Eyupoglu, S. (2020). Does environmental, social and governance performance influence economic performance?. Journal of Business Economics and Management, 21(4), 1165-1184. https://doi.org/10.3846/jbem.2020.12725

Chang, T. W. (2020). Corporate sustainable development strategy: Effect of green shared vision on organization members' behavior. International Journal of Environmental Research and Public Health, 17, 2446. https://doi.org/10.3390/ijerph17072446

Cohen, B., Cowie, A., Babiker, M., Leip, A., \& Smith, P. (2021). Co-benefits and trade-offs of climate change mitigation actions and the Sustainable Development Goals. Sustainable Production and Consumption, 26, 805-813. https://doi.org/10.1016/j.spc.2020.12.034

Comporek, M., Kowalska, M., \& Misztal, A. (2021) The sustainable development of transport companiess in the context of macroeconomic conditions. The case of Central and Eastern European Countries. Entrepreneurship and Sustainability Issues, 8, 3. https://doi.org/10.9770/jesi.2021.8.3(13)

Dziekański, P. (2014). Diversification synthetic indicator for evaluating the financial capacity of local government. The case of Polish voivodeships. Acta Universitatis Agriculturae Et Silviculturae Mendelianae Brunensis, 65(2), 611-619. https://doi.org/10.11118/actaun201765020611

Evers, B. A. (2018). Why adopt the sustainable development goals? The case of multinationals in the Colombian coffee and extractive sector [Master Thesis]. Erasmus University Rotterdam.

Eurostat. (n.d.). Retrieved June 10, 2021, from https://ec.europa.eu/Eurostat

Fedulova, I., Voronkova, O. Y., Zhuravlev, P., Gerasimova, E., Glyzina, M., \& Alekhina, N. A. (2019). Labor productivity and its role in the sustainable development of economy: On the example of a region. Entrepreneurship and Sustainability Issues, 7(2), 1059-1073.

https://doi.org/10.9770/jesi.2019.7.2(19)

Harting, P. (2019). Macroeconomic stabilization and long-term growth: the role of policy design. Cambridge University Press. https://doi.org/10.1017/S1365100519000488

Harymawan, I., Nasih, M., Salsabilla, A., \& Putra, F. K. (2020). External assurance on sustainability report disclosure and firm value: evidence from Indonesia and Malaysia. Entrepreneurship and Sustainability Issues, 7(3), 1500-1512. https://doi.org/10.9770/jesi.2020.7.3(5)

Kekre, R. (2016). Essays on macroeconomic stabilization [Doctoral dissertation]. Harvard University, Graduate School of Arts \& Sciences. https://dash.harvard.edu/handle/1/33493378

Kołodko, G. W. (1993). Stabilization, recession and growth in a postsocialist economy. Economic Journal on Eastern Europe and the Soviet Union, 1, 3-38. https://doi.org/10.1007/BF01101840

Krajnakova, E., Navickas, V., \& Kontautiene, R. (2018). Effect of macroeconom-ic business environment on the development of corporate social responsibility in Baltic Countries and Slovakia. Oeconomia Copernicana, 9(3), 477-492. https://doi.org/10.24136/oc.2018.024

Lisiński, M., Augustinaitis, A., Nazarko, L., \& Ratajczak, S. (2020). Evaluation of dynamics of economic development in Polish and Lithuanian regions. Journal of Business Economics and Management, 21(4), 1093-1110. https://doi.org/10.3846/jbem.2020.12671

Mao, J., Li, C., Pei, Y., \& Xu, L. (2018). Sustainable development companies. In Circular economy and sustainable development companiess. Springer, Singapore.

https://doi.org/10.1007/978-981-10-8524-6_11 
Matinaro, V., Liu, Y., Lee, T. R., \& Poesche, J. (2019). Extracting key factors for sustainable development of companiess: Case study of SMEs in Taiwan. Journal of Cleaner Production, 209, 1152-1169. https://doi.org/10.1016/j.jclepro.2018.10.280

Misztal, A. (2019). Sustainable development of transport companiess in Poland - Statistical assessment. Logistics and Transport, 42(2), 57-64.

Misztal, A., \& Kowalska, M. (2020). Determinants of sustainable development of industrial companiess in Poland in the period from 2010 to 2019 - a statistical evaluation. Research Papers of Wroclaw University of Economics and Business, 64(1), 160-173. https://doi.org/10.15611/pn.2020.1.13

Oberhofer, P., \& Dieplinger, M. (2014). Sustainability in the transport and logistics sector: Lacking environmental measures. Business Strategy and the Environment, 23, 236-253.

https://doi.org/10.1002/bse.1769

Pieloch-Babiarz, A., Misztal, A., \& Kowalska, M. (2021). An impact of macroeconomic stabilization on the sustainable development of manufacturing companiess: The case of Central and Eastern European Countries. Environment, Development and Sustainability, 23, 8669-8698. https://doi.org/10.1007/s10668-020-00988-4

Powe, N. (2020). Sustainable development, sustainability and research within the Journal of Environmental Planning and Management. Journal of Environmental Planning and Management, 63(9), 1523-1527. https://doi.org/10.1080/09640568.2020.1753409

Raczkowski, K. (2015). Zarzadzanie publiczne. Teoria i praktyka. Wydawnictwo Naukowe PWN.

Salari, M., \& Bhuiyan, N. (2018). A new model of sustainable product development process for making trade-offs. The International Journal of Advanced Manufacturing Technology, 94, 1-11. https://doi.org/10.1007/s00170-016-9349-y

Saygili, A. T., Saygili, E., \& Taran, A. (2021). The effects of corporate governance practices on firm-level financial performance: evidence from Borsa Istanbul Xkury companies. Journal of Business Economics and Management, 22(4), 884-904. https://doi.org/10.3846/jbem.2021.14440

$\mathrm{Wu}, \mathrm{S}$., Wu, L., \& Zhao, X. (2021). Can the reform of green credit policy promote companies ecoinnovation? A theoretical analysis. Journal of Industrial \& Management Optimization. https://doi.org/10.3934/jimo.2021028

Škare, M., \& Golja, T. (2013). How important are CSR companies for nations' growth?. Journal of Business Economics and Management, 14(4), 776-790. https://doi.org/10.3846/16111699.2013.820664

Škare, M., \& Hasić, T. (2016). Corporate governance, firm performance, and economic growth - theoretical analysis. Journal of Business Economics and Management, 17(1), 35-51. https://doi.org/10.3846/16111699.2015.1071278

Słupik, S., \& Lorek, P. (2019). Sustainable companies by sustainable product? A case of smart home systems. Ekonomia i Środowisko, 2, 146-159.

Sokolov Mladenović, S., Mladenović, I., \& Ćuzović, D. (2019). Distributive trade and economic growth: EU28 evidence for the period 2008-2015. Journal of Business Economics and Management, 20(3), 489-506. https://doi.org/10.3846/jbem.2019.9857

Suprayoga, G. B., Witte, P., \& Spit, T. (2020). Identifying barriers to implementing a sustainability assessment tool for road project planning: An institutional perspective from practitioners in Indonesia. Journal of Environmental Planning and Management. https://doi.org/10.1080/09640568.2020.1724083

Valjevac, B., Sorak, L., \& Sorak, M. (2018). Development of the strategic planning process necessary for the business performance quality improvement in small and medium companies. Bizinfo Blace, 9, 47-57. https://doi.org/10.5937/bizinfo1801047V

Zikic, S. (2018). A modern concept of sustainable development. Progress in Economic Sciences, 5, 143-151. 